\title{
The Post-glacial history of vegetation and climate at Ennadai Lake, Keewatin, and Lynn Lake, Manitoba (Canada)
}

\author{
By Harvey Nichols, Madison
}

With 5 figs.

\begin{abstract}
$\mathrm{Sum} \mathrm{m}$ a ry. Peat from Keewatin and Manitoba contained macrofossil and palynological evidence of former latitudinal movements of the forest - tundra boundary probably in response to the changing location of the mean summer position of the Arctic front. There was very rapid melting of the large late-Wisconsin icesheet between 8000 and 6000 years B. P., and swift immigration of Picea, with no evidence of tundra vegetation after deglaciation. From 6000 to 3500 years B.P. the Boreal forest extended far north of its present limit, with a short-lived cooler phase about 5000 years ago. This generally warm period was followed by cooler and variable climatic episodes after 3500 B. P. and by a climatic deterioration about 2600 years ago. There was an amelioration between 1500 and 600 B. P., followed by a prolonged cold episode which terminated peat growth in the tundra. The approximate mean summer temperatures at Ennadai Lake have been estimated from the changing location of the northern limit of forest. The radiocarbon dates for these climatic events coincide with a number of changes recorded in the climatic history of northwest Europe.
\end{abstract}

$\mathrm{Zusammenf}$ assung. Torf-Proben in Keewatin und Manitoba (Canada) enthalten Makrofossilien und Pollen, die als Beweis einer Nord-Süd-Verschiebung der Wald-Tundra-Grenze, wahrscheinlich infolge einer Veränderung der mittleren Sommerlage der arktischen Front, gedeutet werden können. Zwischen 8000 und 6000 B. P. ist die ausgedehnte Spät-Wisconsin-Eisdecke rasch geschmolzen, und Picea hat sich sogleich eingestellt, ohne daß Spuren einer Tundra-Vegetation nach Rückgang des Eises auftraten. Von 6000 bis 3500 B. P. dehnte sich das boreale Waldgebiet weit nördlich von seiner jetzigen Grenze aus, nur vorübergehend unterbrochen durch einen kühleren Zeitabschnitt vor ungefähr 5000 Jahren. Dem im ganzen relativ warmen Zeitabschnitt folgte, ungefähr ab 3500 B. P., eine kühlere und stark veränderliche Klima-Periode, und dann eine ausgesprochene Klima-Verschlechterung, die vor etwa 2600 Jahren einsetzte. Anschließend erscheint eine Milderung $\mathrm{zwischen} 1500$ und $600 \mathrm{~B}$. P., gefolgt von einem langen Zeitabschnitt kalter Witterung, mit der das Torf-Wachstum in der Tundra ein Ende findet. Auf Grund der wechselnden Lage der nördlichen Baumgrenze können angenäherte Werte der mittleren Sommertemperaturen am Ennadai-See geschätzt werden. Eine Reihe von ${ }^{14} \mathrm{C}$-Werten für obige Zeitabschnitte zeigt, wenigstens hinsichtlich der Anzahl der Wechsel der genannten Perioden, gute Übereinstimmung mit der Klima-Geschichte Nordwest-Europas.

\section{Introduction}

The forest - tundra boundary in southern Keewatin has been shown by aerial survey to be sharply delineated (LARSEN, 1965a). Continuous forest (defined as greater than $50 \%$ of the ground covered by trees, ibid.) gives way to tundra within about $20 \mathrm{~km}$. The topography of this part of Keewatin is unmarked by breaks in relief or by geological changes; the land is level or gently sloping, and there are no known soil changes which might give rise to this vegetational discontinuity. The division seems to be primarily due to climate (LARSEN, 1965b).

HARE (1951) reviewed the attempts to explain the forest limit in climatic terms, and concluded that none of the explanations was entirely satisfactory. It may prove inadequate to suggest that a single meteorological parameter - such as temperature - should control vegetation growth in this situation, since the plant experiences and responds to a number of climatic parameters.

Recent recognition that the mean summer position of the Arctic front coincided with the tree-line ${ }^{1}$ ) has led to the hypothesis that the extent of the tundra is limited by the

1) 'Tree-line' is here used as a synonym for 'forest limit', but it does not imply the nor hern limit of tree growth. 
presence of the dry cold Arctic airmass during the growing season (BRYson, 1966). Treegrowth begins south of the Arctic front, in territory which in summer is dominated by warm moist Pacific or tropical airmasses. The sum of the climatic parameters is contained in the concept of the airmass, which is a body of air with approximately homogeneous horizontal characteristics, particularly with reference to temperature and moisture (HuschKe, 1959).

If the position of the forest-tundra ecotone in the past has also been controlled by the summer boundary between the Arctic and Pacific airmasses, (that is, the Arctic front), then past movements of the tree-line probably reflected changes in the summer location of the front. An attempt has been made in the present work to estimate the position of the Arctic front from the forest history derived from the pollen diagrams and plant macro-fossil analyses.

There is growing evidence that a number of the major phytogeographic boundaries of North America coincide with airmass boundaries which form frontal zones (BRYson, 1966). If future work confirms that this represents climatic control, then the recognition of past vegetation zones and the mapping of former ecotones may provide a reconstruction of the airmass distribution for the post-glacial period in North America.

The work of BRYSON, IRving \& LARSEN (1965) on the stratigraphy of the foresttundra ecotone in the district of Keewatin, Canada, demonstrated that there were two periods during the post-glacial when there was a northward extension of the Boreal forest beyond its present limit. In the present study these conclusions have been supported and amplified by palynological and macro-fossil analysis from two peat bogs which contain records of vegetational and climatic change.

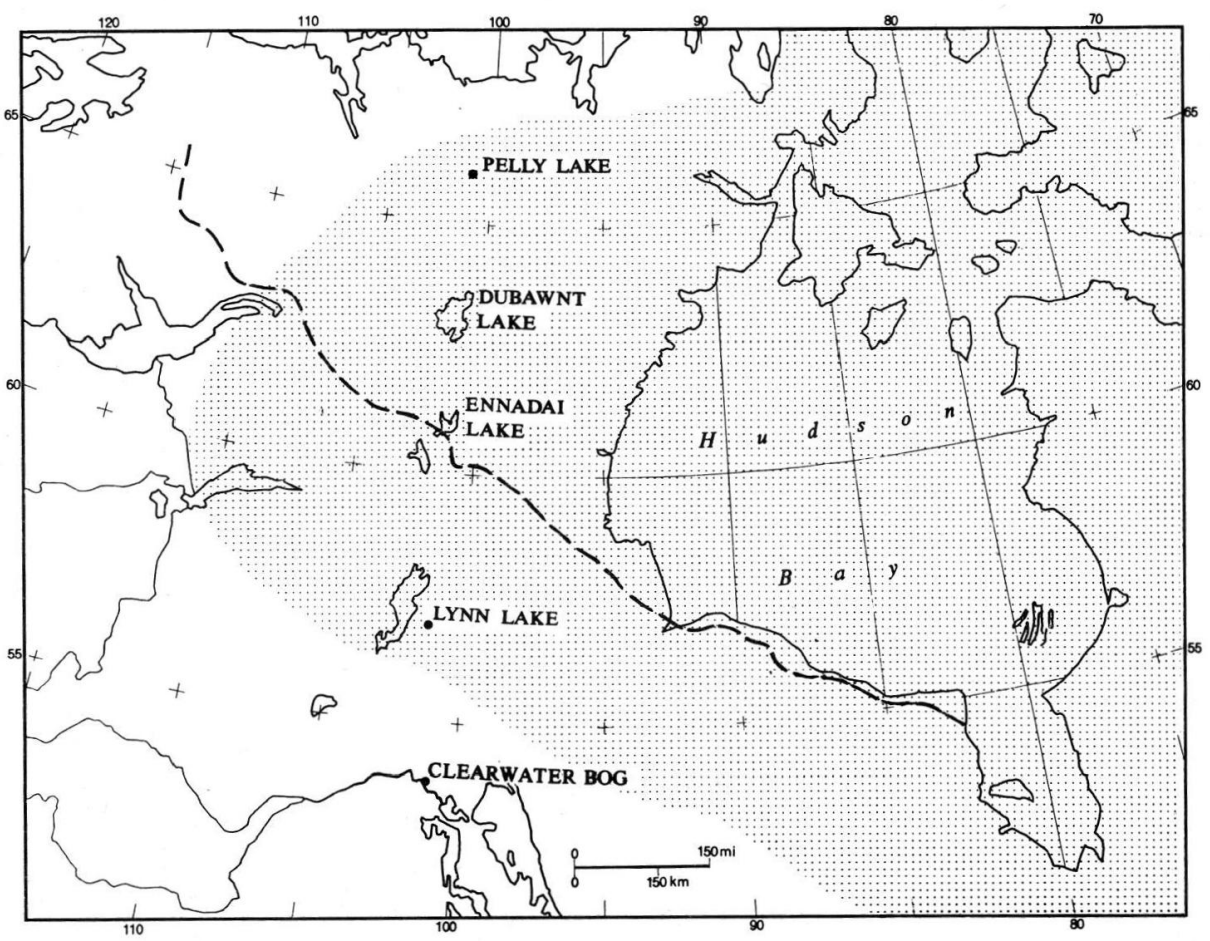

Fig. 1. Location map. The shaded area represents the late - Wisconsin ice-sheet postulated by Falconer, Ives, Løken and Andrews, 1965, (redrawn by permission). The broken line depicts the modern northern limit of continuous forest as mapped by Larsen (1965a). 
This work has initiated a research project at the University of Wisconsin which aims at establishing a north-south transect of sites across North America, in which palynology and radiocarbon dating are being used to examine problems of vegetational history and palaeo-climatic change. These investigations have been concentrated along a line approximating to $100^{\circ}$ West longitude which crosses many of the vegetation zones and airmass boundaries of the continent. It is hoped that the chosen sites will have registered climatically-induced displacements of phytogeographic boundaries.

\section{The Literature}

The present work is closely related to that of other members of the Department of Meteorology who have studied the climate, vegetation and soils of central and northern Canada (particularly Keewatin and Manitoba) for the past decade. Larsen (1964a, 1964b, 1965a, 1966a, 1966b) has investigated the ecology of the modern plant communities, especially in relationship to climate and micro-meteorology. A number of prolonged trips by canoe have been made by him, during which the recording and sampling of archaeological sites (by W. N. IRVING) and fossil soils also took place (BRYSON, IRVING \& LARSEN, 1965). Scores of long reconnaissance and mapping flights have been made over this area to determine the freezing and thawing times of lakes (Peterson, 1965; McFadden, 1965), and the films taken of the terrain have been used to map vegetation boundaries such as the northern edge of the Boreal forest (LARSEN, 1965b). Ground parties have undertaken micrometeorological and permafrost studies throughout this part of Canada (KNollenberg, 1964; Wendland, 1967; LetTau, 1966). Abbreviated and preliminary treatments of the present material have been presented elsewhere (Nichols, 1967a, b).

The work of Ritchie (1956a, b, 1957, 1959, 1960a, b, c, 1962, 1964) on the vegetation of Manitoba has provided a sound base for palaeobotanical studies of that region (Lichti-Federovich \& Ritchie, 1965).

The extent of present knowledge of the vegetational and climatic history of Canada was recently summarised by TERASMAE (1961), but the evidence was mainly from southern and particularly south-eastern Canada. The pattern of events was similar to the familiar Anathermal-Hypsithermal-Hypothermal sequence, but the radiocarbon dates were few, and they were particularly sparse for the Canadian late-Holocene period. It is easier to compare the diagrams described here with the closely-dated sequence of north European climatic changes than with the imperfectly known history of neighbouring parts of Canada (some of which have the drawback of being in different climatic zones). The careful palynological work of RITCHIE (1964) in southern Manitoba can not as yet be compared with the diagrams from Ennadai and Lynn Lake because the upper sections of his cores lack radiocarbon dates.

The dates for the climatic events which are presented in this paper are apparently compatible with those suggested for recent glacial movements in North America by PORTER \& DENTON (1967).

FREDSKILD (1967) has shown that at a site on the west coast of Greenland there is radiocarbon-dated palynological and stratigraphic evidence for climatic change which was compared with North European climatic history. The relevance of his work to the present study is examined below.

\section{The Sites}

The two sites described here lie in the northern part of the Boreal forest and at the tundra edge, locations which may be expected to have recorded movements of the forest limit in response to climatic change. The ecotonal location of Ennadai Lake and also the importance of Sphagnum bog mosses in its stratigraphy has made this more responsive to environmental changes than Lynn Lake. The latter is vegetationally and climatically 
in a more "complacent" situation in the middle of the Boreal forest. The Lynn Lake diagram provides confirmation of the major climatic changes registered at Ennadai.

Peat monoliths were collected from Ennadai Lake, Keewatin $\left(61^{\circ} 10^{\prime}\right.$ N. lat., $100^{\circ}$ $55^{\prime}$ W. long.) and from Lynn Lake in Manitoba ( $56^{\circ} 50^{\prime}$ N. lat., $101^{\circ} 03^{\prime}$ W. long.). Both deposits lie within the Cockburn end-moraine system described by FaLconer, Ives, LøKEN \& ANDREws (1965) (Fig. 1). They believe that this represents a late-Wisconsin icesheet which occupied the Hudson Bay area until at least 8000 years ago. The organic deposits at Lynn Lake and Ennadai did not begin to accumulate until this ice had wasted away, and at Ennadai Lake deposition was probably delayed until after the draining of Glacial Lake Kazan (LEe, 1959). The necron mud which at Lynn Lake overlies the proglacial lake clay has been assigned a date of $6530 \pm 130$ years B. P. (WIS. 72) (BeNDER et al., 1966). The difficulties of sampling permafrozen peat at Ennadai prevented penetration to the minerogenic base, but a date of $5780 \pm 110$ years B. P. (WIS. 67) was obtained for the lowest peat sample.

Ennadai Lake lies at the limit of continuous forest with its northern end in the tundra, while the south end of the lake is surrounded by an open forest composed mainly of Picea mariana, occasional Picea glauca, Larix laricina, Alnus crispa and Salix spp. (LARsen, 1965b). Aerial reconnaissance and ground surveys along the tree-line have indicated that the transition from continuous forest to tundra is quite sharp in this area, taking place within about $20 \mathrm{~km}$., although scattered clumps of Picea mariana are found in favourable sites to the north of the forest border (ibid.). Lynn Lake, about $450 \mathrm{~km}$. south of Ennadai, lies in an area of open sub-Arctic woodland, where spruce forest dominated by Picea mariana constitutes the vegetational climax for the region, with Pinus banksiana serving as the typical pioneer on the open land following severe fire (Ritchie, 1956b).

\section{Clim a te}

The following data illustrate the shortness and aridity of the growing season of the tundra at Ennadai Lake (dominated by Arctic air in summer) and the longer, wetter summer of the Boreal Forest at Lynn Lake (occupied by Pacific and tropical airmasses during the growing season).

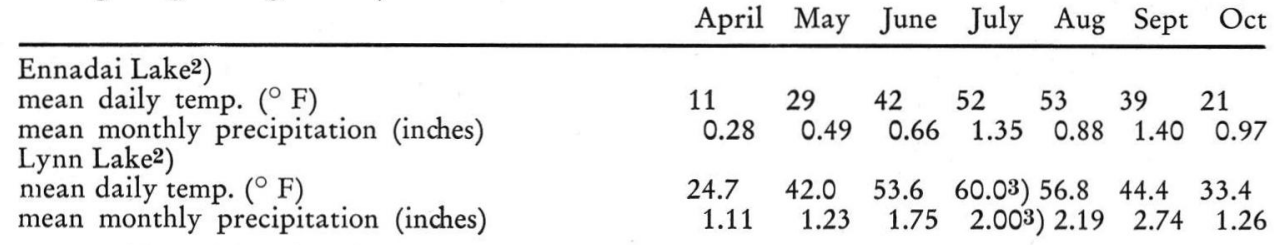

S a m pling Methods

In $1963 \mathrm{~J}$. A. LARSEN cut a continuous vertical section from an exposed peat bank at the northern end of Ennadai Lake. This material was kept wrapped in polythene and under refrigeration until it was used for palynological and radiocarbon purposes. The sampling ceased where permafrost was encountered at the bottom of the bank, and no inorganic base was reached. In sub-Arctic regions where peat rests on impermeable materials (for instance the lacustrine clay at Lynn Lake) the accumulation of water often leads to the formation of ice lenses. It is quite likely that the organic-inorganic interface underlying the Ennadai peat bank lay close to the point at which sampling was abandoned, and that the permafrost was associated with that contact.

It is presumed that Ennadai Lake has had a post-glacial history approximately as long as Lynn Lake, and probably no longer, since Ennadai lay farther away from the edge of the late-Wisconsin icesheet (according to FAlCONER et al., 1965). The basal date

2) These observations cover less than a decade, and are post-1945.

3) estimated. 
from Ennadai (5780 \pm 110 B.P., WIS. 67) is sufficiently close to that of the oldest organic material at Lynn Lake (6530 \pm 130 B. P., WIS. 72) that one supposes that there is no great depth of peat remaining to be excavated from the peat bank at Ennadai Lake.

An exposed peat bank at Lynn Lake was sampled by H. Nichols in 1964. Since the lower metre of peat was permanently frozen, dynamite was employed to shatter the face of the peat bank so that an approximately vertical and almost continuous section of peat could be prised away from the broken face. Sampling by explosives proved to be a hit-ormiss affair, and later trials indicated that a conventional chain-saw could cut out blocks of frozen peat much more satisfactorily (NicHols, 1967c). Where no exposed peat faces exist, dynamite could conceivably be employed to create holes, the sides of which might then be sampled by chain-saw.

Stratigraphy

The following is a shortened account of the stratigraphy recorded from the two sites. After samples were extracted for pollen analysis the peat monoliths were divided into horizontal slices $2 \mathrm{~cm}$ thick for radiocarbon dating and plant macro-fossil analysis.

Monoliths were cut from exposed peat banks at the two sites, and though the exposures were carefully cleaned before sampling, post-depositional events have clearly left their mark in the form of secondary humification, charring of the outer face of the peat, and penetration of the roots of the Ericaceae into older materials.

My thanks are due to Dr. Kunachka and Dr. Koeppen of the Forest Products Laboratory, Madison, Wisconsin, for the identification of wood and charcoal samples of Picea and Larix found in the peat.

\section{En n a d i Lake, Keewatin}

Surface: - covered by living Ledum palustre and Vaccinium vitis-idaea.

\begin{tabular}{|c|c|c|c|}
\hline 0 & 10 & $\mathrm{~cm}$ & Very humified peat, dark brown and crumbly. \\
\hline 10 & -18 & $\mathrm{~cm}$ & $\begin{array}{l}\text { Very humified Sphagnum peat, with Ericaceae roots penetrating from the } \\
\text { outer face of the peat bank. }\end{array}$ \\
\hline 18 & -20 & $\mathrm{~cm}$ & Moderately humified Sphagnum peat. \\
\hline 20 & & $\mathrm{~cm}$ & Fairly fresh $S$ phagnum, but with the outer peat face charred from 26 to $30 \mathrm{~cm}$ \\
\hline 30 & -37 & $\mathrm{~cm}$ & $\begin{array}{l}\text { Dark brown humified Sphagnum peat, with many included charcoal frag- } \\
\text { ments. }\end{array}$ \\
\hline 37 & -44 & $\mathrm{~cm}$ & $\begin{array}{l}\text { Fairly fresh Sphagnum remains, containing charcoal fragments and oc- } \\
\text { casional grains of sand. Outer peat face more humified. }\end{array}$ \\
\hline 44 & -50 & $\mathrm{~cm}$ & $\begin{array}{l}\text { Very fresh unhumified Sphagnum peat, with a few Cyperaceae stems and } \\
\text { a leaf of Vaccinium vitis-idaea. }\end{array}$ \\
\hline 50 & -59 & $\mathrm{~cm}$ & $\begin{array}{l}\text { Sphagnum-Cyperaceae peat, with many leaves of Vaccinium vitis-idaea, } \\
\text { and one leaf of Ledum palustre. }\end{array}$ \\
\hline 59 & 61 & $\mathrm{~cm}$ & Charcoal horizon, containing Picea needles. \\
\hline 61 & & $\mathrm{~cm}$ & $\begin{array}{l}\text { Unhumified Sphagnum peat, with many Picea needles and some stems of } \\
\text { Cyperaceae. Outer peat face charred. }\end{array}$ \\
\hline 68 & & $\mathrm{~cm}$ & Fresh Sphagnum, with many Picea needles and some Cyperaceae stems. \\
\hline & & $\mathrm{cm}$ & $\begin{array}{l}\text { Fresh Sphagnum peat with many Cyperaceae rhizomes and a few Picea } \\
\text { needles. Occasional leaves of Vaccinium vitis-idaea and Ledum palustre. }\end{array}$ \\
\hline \multirow{2}{*}{\multicolumn{3}{|c|}{$\begin{array}{l}75^{1 / 2}-76^{1 / 4} \mathrm{~cm} \\
76^{1 / 4}-84 \mathrm{~cm}\end{array}$}} & Burnt Sphagnum peat, with small charred twigs. \\
\hline & & & $\begin{array}{l}\text { Fresh unhumified Sphagnum, containing many Cyperaceae stems and remains } \\
\text { of Polytrichum mosses. }\end{array}$ \\
\hline 84 & -91 & $\mathrm{~cm}$ & $\begin{array}{l}\text { Charcoal horizon, with carbonised leaves of Vaccinium, Ledum and Picea, } \\
\text { burnt Ericaceae roots, and partially charred piece of Larix wood measuring } \\
10 \times 10 \times 3 \mathrm{~cm} \text {. }\end{array}$ \\
\hline & $951>3$ & $\mathrm{cn}$ & Fresh Sphagnum peat containing Cyperaceae rhizomes. \\
\hline & & & Charred peat, with carb \\
\hline & & $\mathrm{cn}$ & Fresh Sphagnum peat with Cyperaceae stems and some Pice \\
\hline & & & $\begin{array}{l}\text { As above, but outer peat face is charred and has burnt Picea needles and } \\
\text { Ledum leaves. }\end{array}$ \\
\hline & - & & $\begin{array}{l}\text { Charcoal horizon, with burnt Picea and Ledum leaves, Cyperaceae stems } \\
\text { and unidentified twigs. }\end{array}$ \\
\hline & & & derately humified Stharaum neat \\
\hline
\end{tabular}




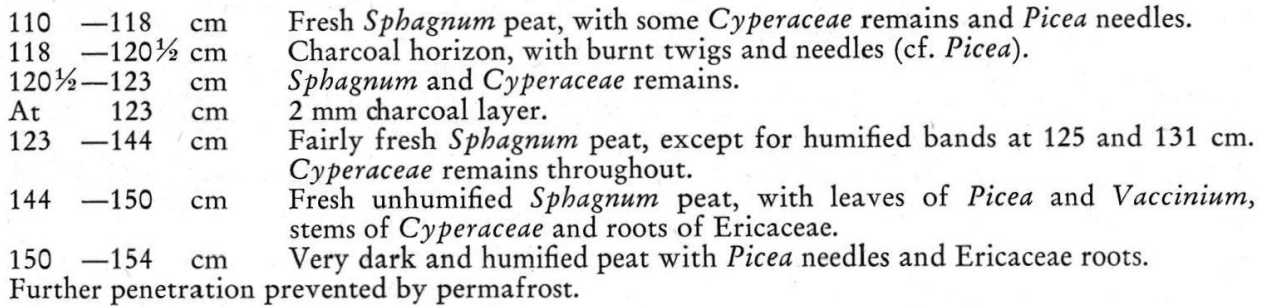

Lyn $\mathrm{n}$ Lake, Manitoba

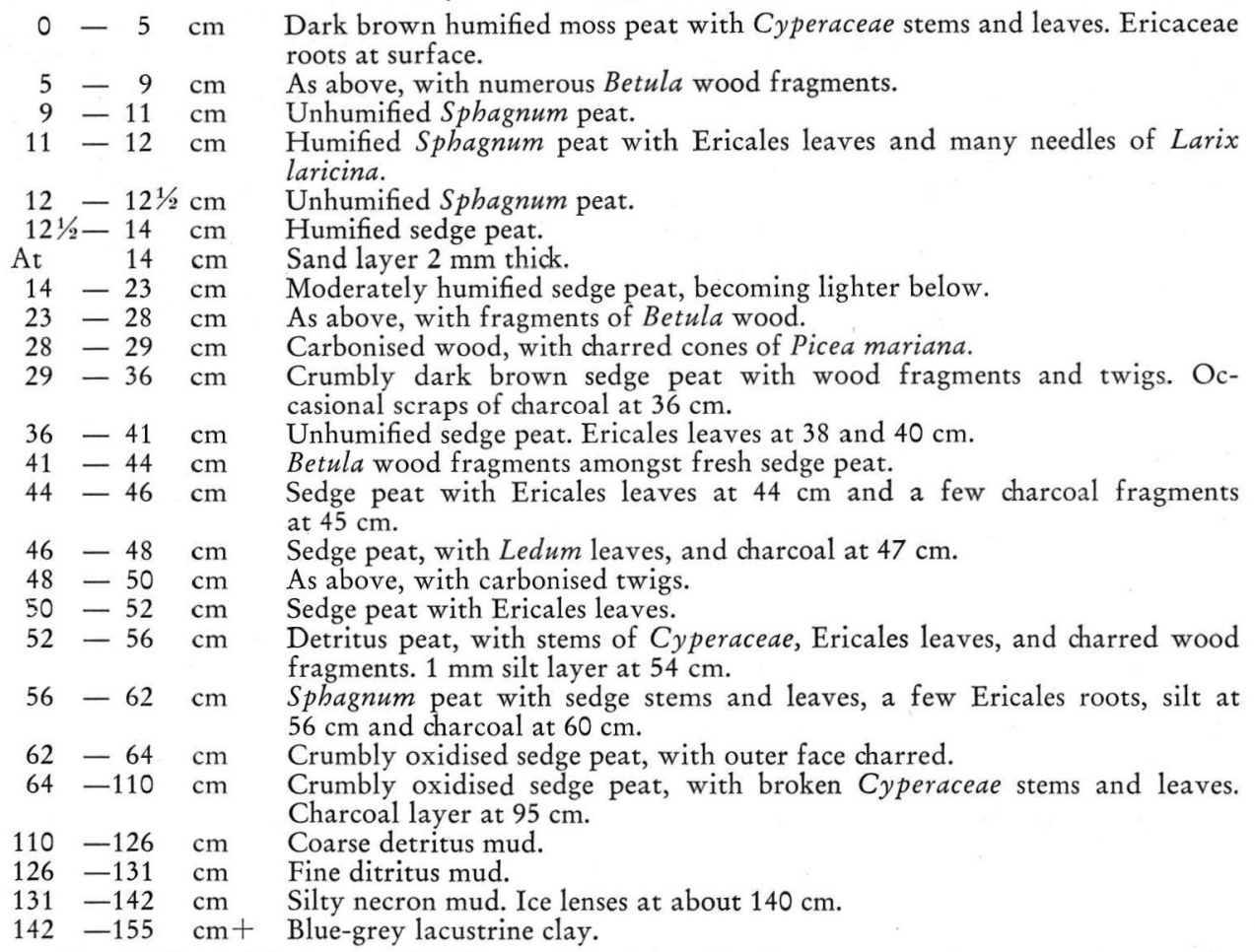

Dr. W. S. G. MAAss was kind enough to identify the mosses making up peat samples from some points in the Ennadai monolith, and to make some comments on the possible significance of the constituents (written communication). The following is a summary of his remarks:
Depth Identity
$50 \mathrm{~cm}$ Sphagnum fuscum KlingGr. and possibly S. rubellum Wils. A few perichaetia were present.
$70 \mathrm{~cm}$ Same as above, one perichaetium.
$115 \mathrm{~cm} \quad$ S.fimbriatum WILs., S.girgensobnii Russ. No perichaetial leaves de- dected.
$130 \mathrm{~cm}$ Possibly S.girgensobnii, and per- haps S.robustum RöLl.
$135 \mathrm{~cm}$ Possibly S.girgensobnii and / or

Possible significance Hummock-forming species, possibly indicative of drier and more acidic conditions.

Possibly wet horizon, with this and the lower samples existing in either a tundra, an open forest over mineral ground, or amidst bushy fen vegetation. 
The peat bank at Ennadai Lake is composed primarily of Sphagnum bog mosses in varying states of humification. The significance of atmospheric moisture to the growth of Sphagnum makes it possible to gain some idea of the precipitation-evaporation budget from the rate of Sphagnum growth and the degree of humification (or oxidation) of the peat. In northern Europe this concept has resulted in the recognition of wetter and drier episodes from the "recurrence surfaces" and "retardation layers" in the peat bogs (GoDwin, 1954, 1960). I suggest that at Ennadai the very fresh unhumified pale-brown Sphagnum peat (which often contains very high percentages of Sphagnum spores) accumulated under relatively warm, wet conditions, when the Arctic front lay to the north of the site. I think that the dark-brown humified peat (with low Sphagnum spore counts) represents drier and colder periods, when the Arctic airmass occupied Ennadai in summer. At the present day a southward extension of the average summer position of the Arctic front causes the associated stormtrack to affect more southerly latitudes than before. Ennadai, lying north of the frontal zone, experiences colder and drier conditions at the same time as sites to the south get colder and wetter. When the frontal zone is far to the north Ennadai enjoys warmer and wetter conditions while more southern locations are drier since they are missed by the stormtrack.

The peaks of Sphagnum spore numbers recorded in the Ennadai diagram are often associated with changes in peat humification, some of them not very clearly marked. The growing season is short at Ennadai Lake and for most of the year the surface of the peat is frozen and is not subject to oxidation. At this site the production of Sphagnum spores seems to be an additional indicator of environmental change which supports and amplifies the evidence of peat humification, a conclusion which is supported by work by TALLIS (1964), TsukAda (1966) and Fredskild (1967) in peat studies in northern England, central Japan and the west coast of Greenland. In these three studies peaks of Sphagnum spores coincide with bands of unhumified peat. A similar relationship has been noted in a pollen diagram from central Manitoba (Nichols, 1967e). Tyrrell (1910) noted that Sphagnum bogs were found extensively in the lowland woods of northern Manitoba, and that they reached to the northern limits of the forest; Sphagnum growth appears to be inhibited by the cold dry Arctic air which occupies the tundra.

The Pollen Diagrams: Vegetational and Climatic History

The total pollen sum counted (excluding Sphagnum) was 300 grains which was expressed as $100 \%$, most of which consisted of tree pollen (especially Picea and Pinus). In expressing Sphagnum values the spore numbers were related to the 300 grain counts which were treated as $100 \%$. The rest of the slide was scanned to locate infrequent pollen grains not encountered in the initial sum. Counts of more than 300 grains from this material do not appear to alter the percentages significantly, and it is felt that scanning is a more efficient method of locating uncommon grains than recording large numbers of more prevalent pollen.

\section{0 to 6000 Years B.P.}

The late-Wisconsin icesheet which covered this area at least as late as 8000 years B.P. (FALCONER et al., 1965) seems to have melted very rapidly. By 6500 years ago accumulation of organic mud had begun at Lynn Lake, while prior to 5800 years B. P. at Ennadai not only had the ice disappeared but in addition Glacial Lake Kazan had drained sufficiently to allow formation of terrestrial peat. Ennadai Lake is approximately 300 miles $(480 \mathrm{~km})$ from the nearest end moraines mapped by FALCONER et al. (1965) so that the icesheet covering that distance seems to have disappeared within a maximum period of 2000 years. A relatively warm climate (suggested by high percentages of Alnus and Picea pollen at the base of the pollen diagrams) seems to have characterised this 


\section{ENNADAI LAKE, KEEWATIN, $1965 \sum_{\sum^{A P}+N A P=300,}$}

excluding Sphagnum

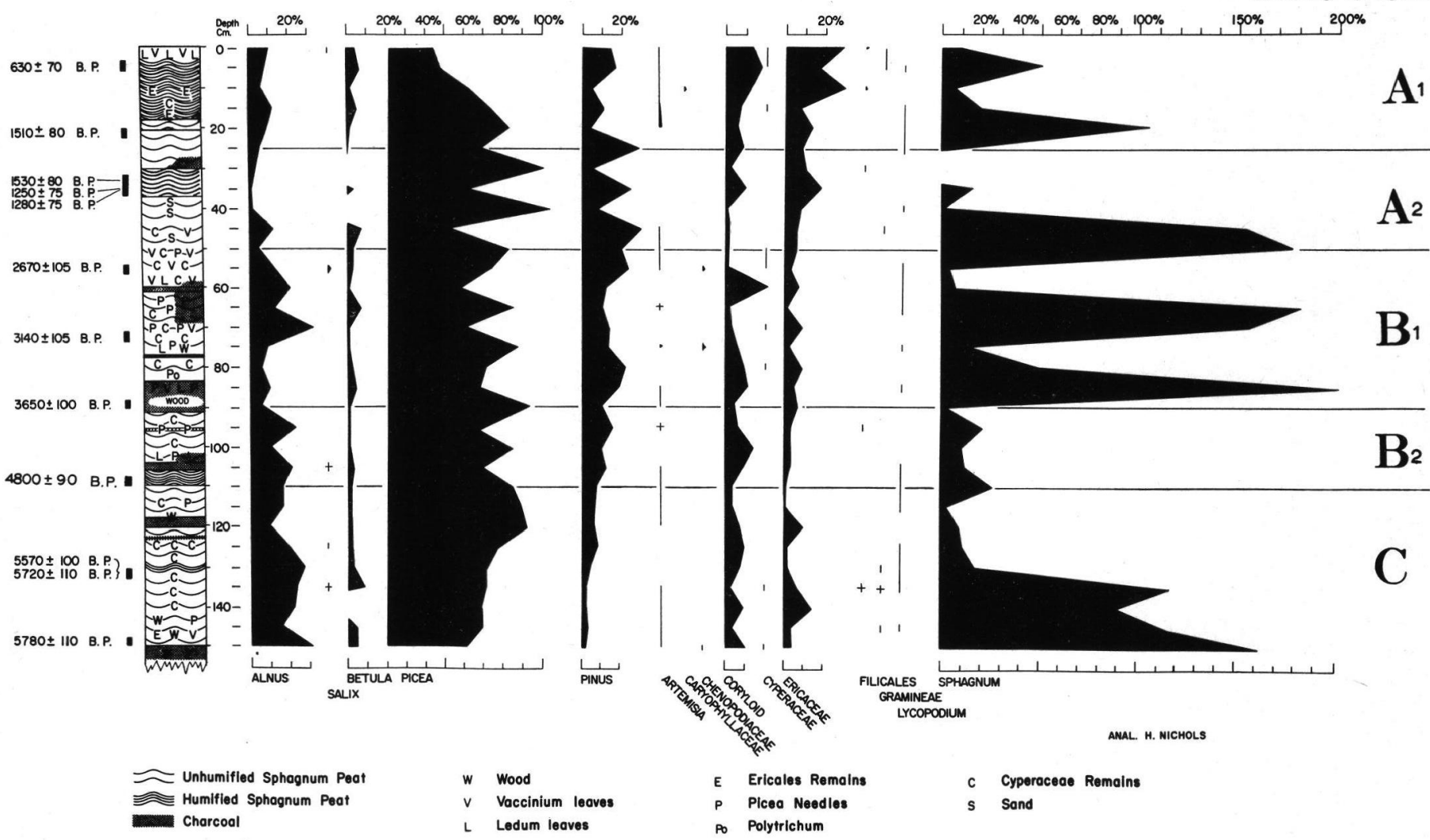

Fig. 2. Pollen diagram from the northern end of Ennadai Lake, Keewatin, Northwest Territories. 
LYNN LAKE, MANITOBA, 1965

$\sum A P+N A P=300$, excluding Sphognum

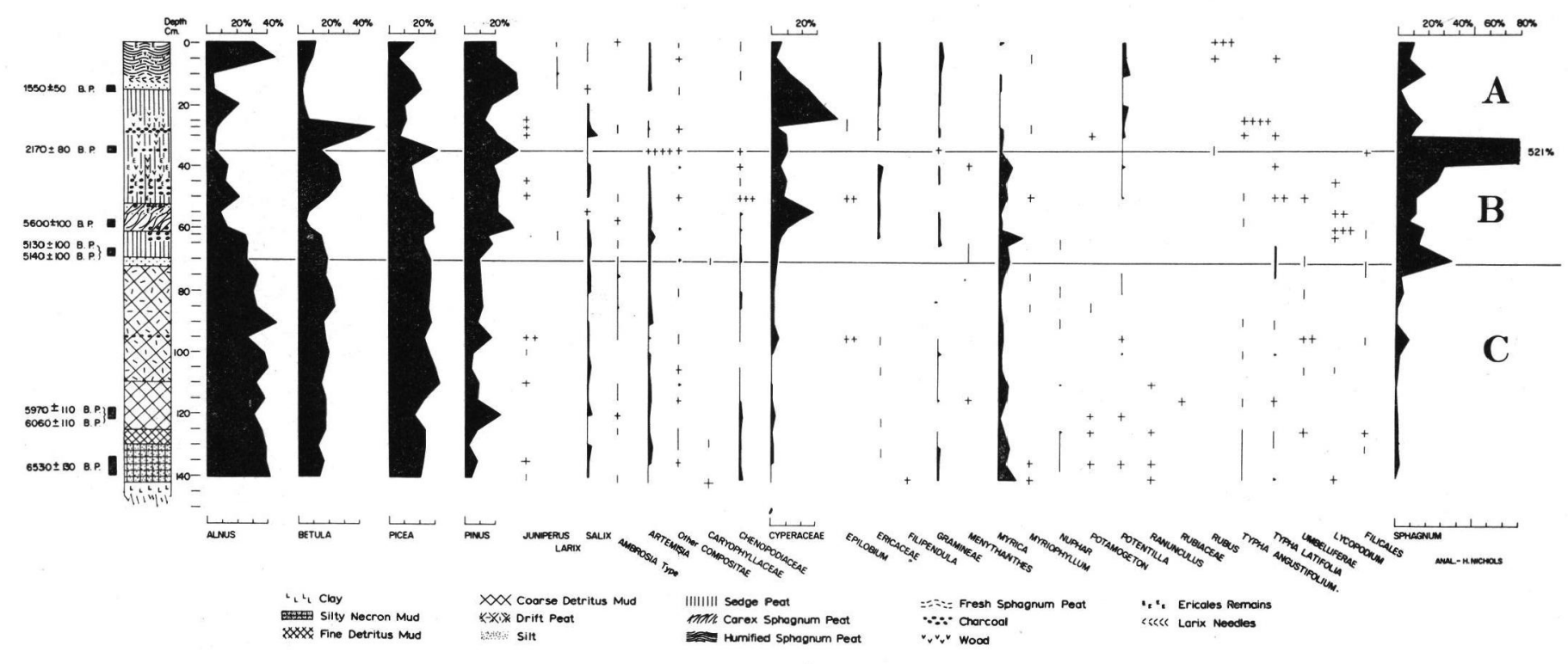

Fig. 3. Pollen diagram from Lynn Lake, Manitoba. The crosses mark grains found while scanning the slides, which were not included in the pollen sum. 
period, and this probably explains the swift wasting of the ice. Presumably this became a rapidly thinning sheet of "dead ice" and disappeared more or less contemporaneously by down-melting over a large area. It is interesting to note that the major post-glacial rise of sea-level was accomplished during this period (GodwIn, SUGGATE \& WILlis, 1958).

The high Sphagnum spore percentages and the presence of Sphagnum girgensobnii and possibly S. robustum in the unhumified peat at Ennadai point to a relatively wet climate. I suggest that at this time (about 5800 years ago) the mean summer position of the Arctic front was close to and probably somewhat north of Ennadai peat bank. This would result in rain at the frontal zone and to the south during the growing season, and the spruce trees and Sphagnum bogs would thrive in the warm, moist southerly air.

It is apparent from the pollen diagrams that shortly after the melting of the icesheet there was a considerable cover of spruce and alder established in northern Manitoba and southern Keewatin. The low values for non-arboreal pollen at the base of both diagrams plus the presence of Picea needles in the peat at Ennadai suggests that any tundra which may have fronted the ice was of very limited extent and was swiftly replaced by open spruce forest. The moderate but increasing percentages of Picea pollen at the base of these diagrams suggests the continued migration of spruce trees onto a recently deglaciated landscape under ameliorating climatic conditions. The spruce trees and alders probably grew very close to the ice margin or even on the morainic surface of the glacier itself as they do today in Alaska (SHARP, 1958) where the cooling effect of the ice extends only a few hundred metres from the glacier. Picea may have migrated over the freshly-exposed ground as quickly as the ice retreated. It traversed at least 300 miles $(480 \mathrm{~km})$ within approximately 2000 years (at most) to reach Ennadai Lake by $5780 \pm 110$ years B.P. (Wis. 67), a minimum mean rate of 15 miles $(24 \mathrm{~km}$ ) per century.

The period 8000 to 6000 years B. P. in northwestern Europe fell within the warmest period of the post-glacial, the so-called Climatic Optimum (Godwin, 1956). The rapid deglaciation of central Canada and the swift immigration of the forest suggests that the two regions shared a substantial climatic amelioration at the same time.

6000 to 5000 Years B.P.

From the base of both diagrams to about 5000 B. P. there are low Sphagnum values and high counts of Alnus and Picea pollen at both sites. Spruce dominated the Ennadai scene, while at Lynn Lake there was a considerable element of alder in the spruce forest. The identification by Dr. MaAss of Sphagnum fimbriatum, S. girgensohnii and perhaps $S$. robustum in the peat at Ennadai possibly indicates relatively wet conditions. During this time the forest extended far north of Ennadai, suggesting a more northerly summer position for the Arctic front. It seems likely that this represented a warm period, characterised possibly by the presence of Pacific airmasses in southern Keewatin (in summer) as the Arctic airmass was displaced Poleward. It was probably during this period that podsolic soils were being formed under spruce forest as far north as Dubawnt Lake $\left(63^{\circ} 02^{\prime}\right.$ N. lat., $100^{\circ} 48^{\prime}$ W. long.) which is due north of Ennadai and $280 \mathrm{~km}$ beyond present tree-line (BRYSON et al., 1965). It is calculated that this represented a rise in the mean summer temperature of about 3 degrees C. above present values at Ennadai (see Fig. 5).

In Europe this was the late Atlantic pollen zone, which falls within the period of the "Climatic Optimum". The estimated summer temperatures in northern Europe at that time were 2-3 degrees C. higher than at present (Godwin, 1956). The amplitude of the temperature fluctuations appears to have been greatest in high latitudes (LAMB, 1963).

At $5140 \pm 100$ years B.P. (Wis. 112, Bender et al., 1966) the Lynn Lake pollen diagram registered a decline in Picea and Alnus and a peak of Sphagnum, while at 
Ennadai $4800 \pm 90$ years B.P. (WIs. 166) Picea experienced its first major decline. At this level in the Ennadai stratigraphic record unhumified Sphagnum peat was replaced by moderately-humified peat (at $110 \mathrm{~cm}$ ). A stratigraphic change is seen at Lynn Lake at approximately the same time, $5140 \pm 100$ B.P. (WIs. 112) when drift peat was superseded by sedge peat at $70 \mathrm{~cm}$. The thin layer of silt which separates the two peat types may represent some local disturbance of minerogenic material by rainwash or by increased lake level. The palynological evidence seems to have recorded an opening up of the spruce forest, and perhaps a southward retreat of the forest limit in Keewatin, conceivably as a result of a cooling trend in climate.

About 5000 years ago in northern Europe, the sub-Boreal period began with the "elm decline", a feature which may have reflected climatic change or cultural disturbance, or both (Iversen, 1941, 1960; Godwin, 1956; Troels-Smith, 1960; Smith, 1961, 1965). The vegetation changes resulting from the expansion of Neolithic agriculture at that time may have obscured the effect in the pollen diagrams of any north European climatic changes which occurred, so that the question remains unsettled.

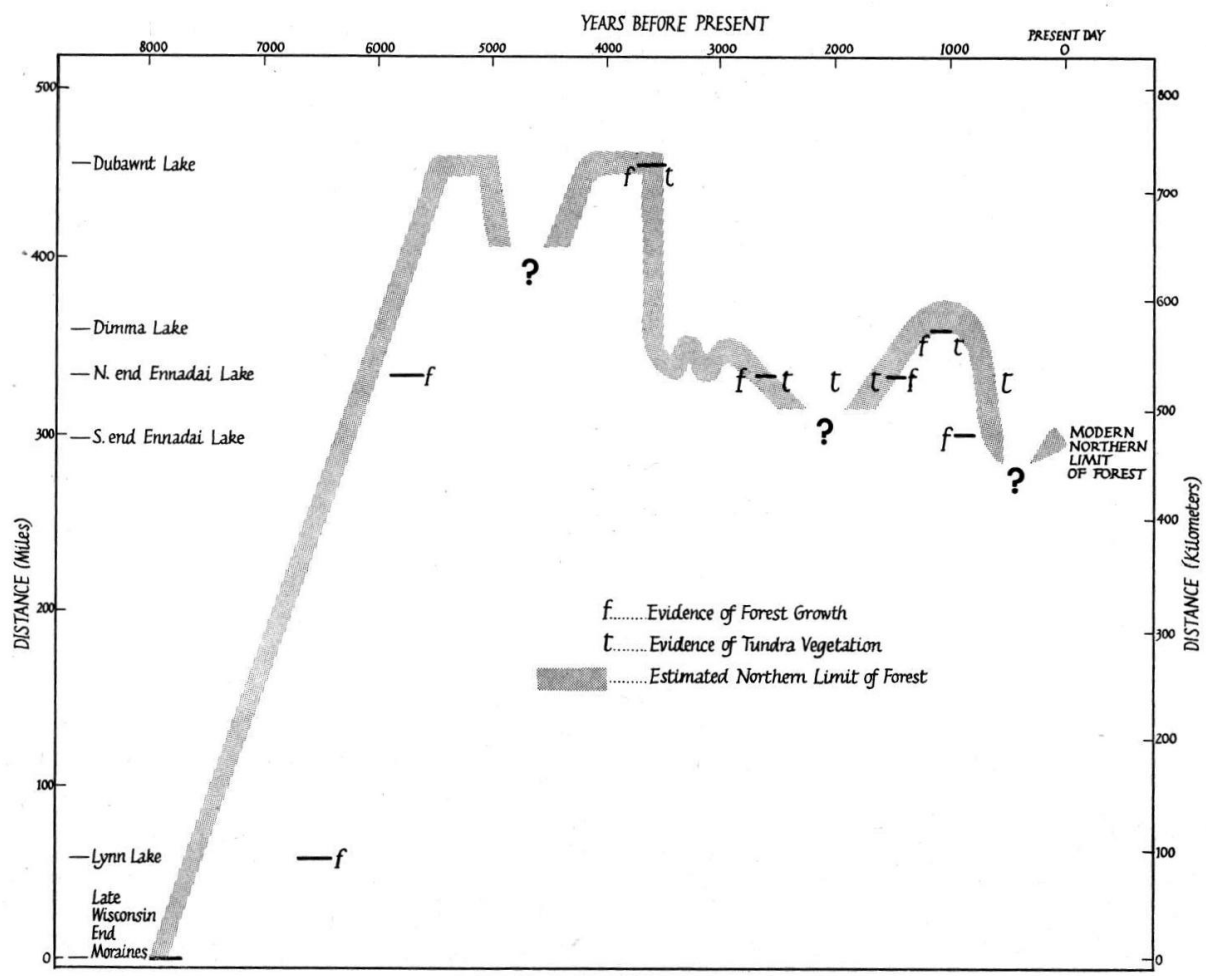

Fig. 4. A tentative reconstruction of the location of the northern limit of continuous forest along the meridian $100^{\circ} \mathrm{W}$. in central Canada. Stratigraphic evidence for forest $(f)$ or tundra $(t)$ is shown by short horizontal lines which represent the radiocarbon date and the standard deviation. The rest of the diagram is based on the pollen diagrams from the north end of Ennadai Lake and from Lynn Lake, and this palynological and stratigraphic evidence is less unequivocal. For instance, the vegetation changes following $5000 \mathrm{~B}$. P. and from 3500 to $2500 \mathrm{~B}$. P. are derived from radiocarbon-dated palynological evidence, but there is no clear stratigraphic evidence of a change from forest to tundra, so that the magnitude of the ecotonal movements can only be inferred. It is not known how far south of Ennadai the forest retreated between 2500 and 1500 B. P. and after 600 B. P. 


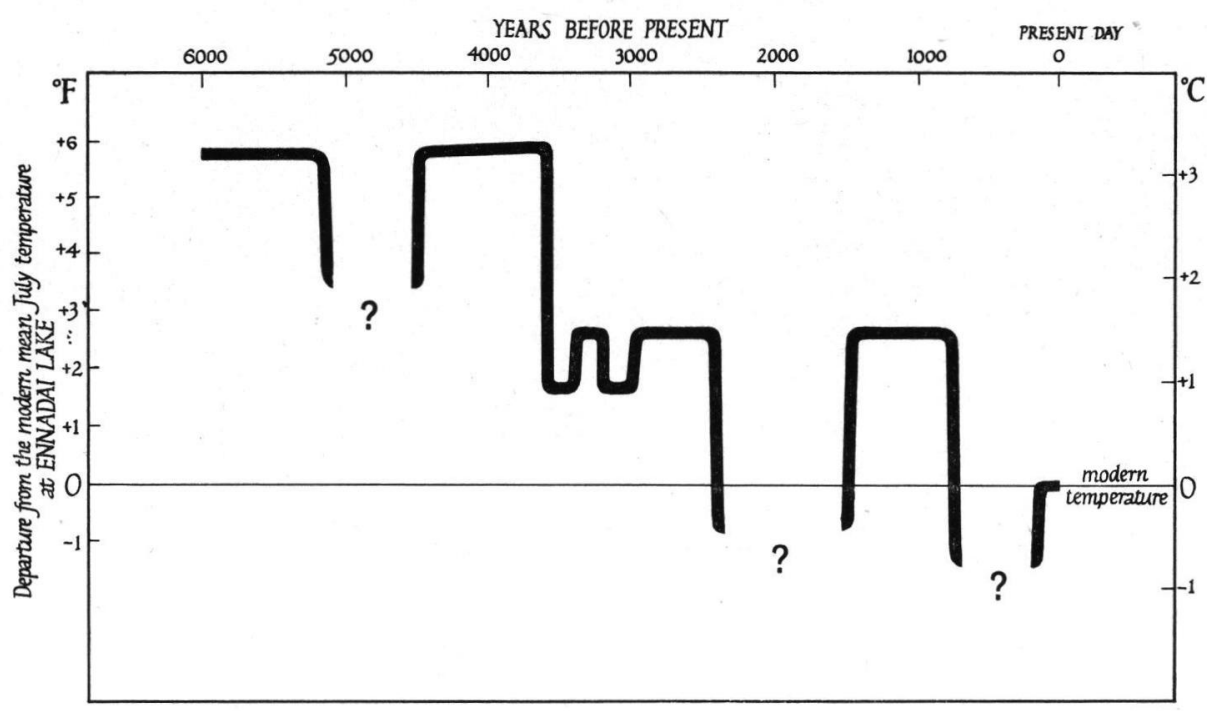

Fig. 5. Estimated changes in the mean July temperatures at Ennadai Lake, Keewatin, derived from Figure 4. The departures from the modern means were calculated from the distance of the forest limit from Ennadai. When, for example, the forest extended $200 \mathrm{~km}$ north of Ennadai Lake it was assumed that the temperature at Ennadai resembled that now found $200 \mathrm{~km}$ to the south of that site. The probable error is thought to be $\pm 1 / 2^{\circ} \mathrm{C}$. The climatic data were from post 1945 observations covering less than a decade. - The magnitude of the cooling after 5000 B. P. is not known, beyond the fact that temperatures were not as low as modern figures. The deterioration from 2500 to 1 '500 B. P., and following 600 B. P., witnessed summer temperatures below modern values, but the amount of cooling is unknown (see comments on Figure 4).

5000 to 3500 Years B.P.

From about 5000 to 3500 years ago at Ennadai Picea had high but varied percentages, with increased but low counts of Sphagnum spores. Pinus registered a small increase. At Lynn Lake there was also a rise in Pinus percentages and a Sphagnum peak following $5140 \pm 110$ B.P. (WIs. 112). At Ennadai at $3650 \pm 100$ B. P. (WIs. 80) there was a charcoal layer which contained partially-burned wood (Larix) and carbonised Picea needles, after which Picea pollen declined and Sphagnum rose to very high values. Immediately above the top of the charcoal layer $(84 \mathrm{~cm})$ macro-fossils of Polytrichum mosses were identified. There was a stratigraphic change at Lynn Lake at 54 to $62 \mathrm{~cm}$ in which Sphagnum remains appeared in the sedge peat at the same level as a decline of Alnus and Betula percentages. Picea and Pinus seem to have benefitted from this change. A sample from 58 to $60 \mathrm{~cm}$ was submitted for radiocarbon assay, but the result, $5600 \pm$ 100 B. P. (WIs. 131, BENDER et al., 1967), is inconsistent with the rest of the diagram and may be ignored.

Initially this was a cooler period at both sites, the first deterioration from the time of maximum post-glacial warmth. It was, however, still quite warm, for the tree-line was still north of Ennadai, and after the cooling at about 5000 B. P. the forest may have moved north again to its former extent. Podsolic soils were formed under coniferous forest during this time at Dubawnt Lake, $220 \mathrm{~km}$ north of Ennadai Lake (BRYson et al., 1965). The podsols were capped by a burned forest horizon dated $3430 \pm 100 \mathrm{~B}$. P. (Wis. 12) (BENDER et al., 1965) which was covered by tundra soils, indicating that forest regeneration did not take place after the fire.

The fire which occurred at Ennadai at 3650 B. P. destroyed the local spruce forest. The presence of Polytrichum remains in the peat suggests that this moss pioneerd the 
regeneration of vegetation on the land cleared by fire, since it is a colonist of bare mineral soils (particularly sand) in the central Canadian Arctic. It is suggested (BRYson et al., 1965) from the evidence at both Dubawnt and Ennadai Lakes that a major climatic deterioration took place there approximately 3500 years ago. The summer position of the Arctic front and the tree-line apparently moved south, which probably resulted in more frequent frontal storms at Ennadai.

At Pelly Lake in northern Keewatin ( $66^{\circ} 05^{\prime}$ N., $101^{\circ} 04^{\prime}$ W.) lacustrine mud has been exposed by a reduction in lake level. The basal organic material (dated $3360 \pm 70$ B. P., Wis. 216, Bender et al., unpub.) had higher percentages of Picea and Pinus pollen than have modern surface samples. It is suggested (Nichols, 1967d) that this might have reflected a treeline which lay farther north than now, and that there were more frequent southerly or westerly winds at the site during summer. The organic bed is shallow (less than $40 \mathrm{~cm}$ ) and there is little change in the pollen percentages throughout the deposit, so that it is likely that it represents only a short span of time. The lacustrine mud passes conformably upwards into rootlet peat, which appears to have ceased to accumulate owing to drier (and therefore in this region probably colder) climatic conditions shortly after $3360 \pm 70 \mathrm{~B}$. P.

The dates for the forest fires at Dubawnt and Ennadai are very similar, and it is possible that they represent the same catastrophe. It is appropriate to interject at this point a discussion of the possible significance of forest fires in the vegetational and climatic history of this area.

\section{Climate and Fire}

Fires caused by lightning generated by thunderstorms commonly occur in those areas of central Canada dominated by Pacific air which are near to the scene of frontal activity. At the front itself the fires are infrequent and short-lived because the region is affected by frontal rain, but field reports (personal communications by R. A. BRYson and J. A. LARSEN) have recorded numerous fire-scars in the northern part of the Boreal forest south of the summer position of the Arctic front. By contrast, the territory north of the Arctic front, dominated by cold dry stable air, experiences few fires, but when they start there is usually no rain to extinguish them. Extensive lightning fires in central Canada are therefore likely to be associated with long-term climatic changes, as well as ephemeral meteorological effects.

As far as one can judge from the very limited state of present knowledge, a prolonged southward shift of the mean summer position of the Arctic front would leave the trees growing north of the front particularly susceptible to fire as well as to the difficulties of regeneration. A fire produced by lightning (or some other natural agency) might then sweep unchecked through the forest which had been killed and/or desiccated by the cold dry Arctic air during the growing season. This may explain why major burned forest horizons at four sites in Keewatin ranging from Dubawnt Lake to Ennadai Lake (a northsouth distance of $220 \mathrm{~km}$ ) have essentially the same age: $3430 \pm 110$ (Wis. 12), $3550 \pm$ 120 (Wis. 18), $3650 \pm 100$ (Wis. 80), and $3540 \pm 110$ (Wis. 52) (BENDER et al., 1965, 1966); these may represent one enormous conflagration. The soils evidence is that this occurred at a time of climatic deterioration, and it is conceivable that the desiccation of the spruce trees as the summer limit of Arctic air extended south into the forest encouraged the widespread burning.

FREDSKILD's (1967) pollen and macro-fossil analyses of peat from the west coast of Greenland (Sermermiut, Jakobshavn) recorded four peaks of charcoal particles (about the same size as pollen grains) derived from local cultural activity or possibly from longdistance transport from forest fires in Canada (ibid. p. 45, and Plate VI). Two of these 
peaks coincide with peaks of Cyperaceae pollen and Sphagnum spores attributable to wetter conditions locally, and a third maximum is contemporaneous with an intermediate moist period (ibid. p. 45). FrEDSKILD has recorded four maxima of long-distance transported pollen (not native to Greenland) which occur at the same time as the peaks of microscopical charcoal.

The basal peak of particulate charcoal at Sermermiut was dated $3510 \pm 120 \mathrm{~B} . \mathrm{P}$. to $3360 \pm 120$ B.P. This coincides with the very extensive fire or fires which destroyed the forest between Dubawnt and Ennadai Lakes in Keewatin (a north-south distance of $220 \mathrm{~km}$ ) at $3430 \pm 110$ B. P., $3550 \pm 120$ B. P., $3650 \pm 100$ B.P., or $3540 \pm 110$ B.P. (see above). This devastation occurred at a time of climatic deterioration (BRYSON et al., 1965; see above). The west to east circulation of the atmosphere in this region could be expected to carry burned material from Canada to Greenland, particularly if the fire occurred in summer (as is most likely). The summer air trajectories are at times direct from Keewatin to Greenland. The atmospheric turbulence associated with the fire(s) and the size and density of the charcoal fragments are such that it is theoretically very likely (from a consideration of Stokes' law) that such material should have been transported from the area of Ennadai Lake to the west coast of Greenland. It is possible that there were other large forest fires in central and eastern Canada about 3500 years ago, particularly in view of the suggested association with climatic change, so that it is conceivable that the charcoal at Sermermiut came from areas of Canada which are closer to Greenland than is Ennadai Lake.

Charcoal, exotic pollen, and high Sphagnum spore percentages have coincident peaks in the stratigraphic units 8 and 11 in the pollen diagram Sermermiut B (FrEDSKILD, 1967, plate VI). The parallel representation of charcoal and alien pollen suggests again that the charcoal may have been transported a long distance, along with the exotic pollen; perhaps both derived largely from Canada. The peaks of Sphagnum spores and the change to unhumified Sphagnum peat at these same levels makes possible the inference that the peaks of charcoal and exotic pollen occurred at times of climatic change (at ca. $2350 \pm 110$ B.P. and $1540 \pm 100$ B.P.). It then becomes interesting to speculate that a change in the atmospheric circulation which brought about rapid Sphagnum peat growth and sporogenesis at Sermermiut might also have involved a shift in wind direction (during summer), so that particulates from North America were more likely than at other times to settle on the west Greenland coast. It is also possible that the atmospheric turbulence produced by burning dispersed North American pollen farther than usual.

The possibility that some of the charcoal resulted from anthropogenic factors may not be entirely unrelated to the speculation concerning the possible link with climatic change. For example, during the Scandinavian settlement of southern Greenland in the warm period prior to the thirteenth century A. D. there was little contact with Eskimos. It has been surmised that the latter group occupied northern Greenland during this favourable climatic episode (cf. The Vinland Sagas). The climatic deterioration of the thirteenth and fourteenth centuries A. D. forced the Eskimos back into southern Greenland, where they fought with the Scandinavian settlers (ibid.). It is conceivable that the coincidence of charcoal peaks and climatic changes at Sermermiut may partly have reflected cultural migration induced by climatic variations.

It is difficult to know to what extent stratigraphic hiatuses may have been created by burning at the two Canadian sites, but the radiocarbon dates are sufficiently closelyspaced and consistent that this does not appear to have produced any long gaps in deposition. Numerous charcoal horizons in the stratigraphic records from Ennadai and Lynn Lakes point to the occurrence of frequent fires between approximately 5000 and 1500 years B. P. 


\section{0 to 2500 Years B.P.}

In the following period, about 3500 to 2500 years B.P., there were very varied Sphagnum percentages, accompanied at Ennadai by variations in peat humification. Picea representation was irregular at Ennadai, while at Lynn Lake Alnus declined as Pinus and later Betula rose. The rapid fluctuations in the behaviour of Sphagnum and Picea suggest variable environmental conditions at Ennadai, while there were less extreme changes at Lynn Lake. The charcoal layers in the Ennadai peat indicate that some of the sharp falls in spruce pollen percentages were due to fire, but this does not explain the rapid changes of Sphagnum spore production and peat composition. It is possible that during this cooler period the summer position of the Arctic front was in the general area of Ennadai Lake. In that situation short-lived movements of the front to north and south of Ennadai would have resulted in exposure of the site to frontal storms alternating with drier episodes. The spruce forest may have had time during these periods to move north for a few miles under favourable climatic conditions, and then for the advance to have been negated by a southerly extension of Arctic air. The desiccation of the forest during cold periods may have made it more vulnerable to burning.

It is also possible that prevailing wind direction may have had an influence on the representation of Picea pollen in the Ennadai diagram. There is little long term climatic data from the central Canadian Arctic, but the little that exists, added to experience during fieldwork, suggests that in summer areas which lie north of the forest limit are characterised by dominant winds from the north-out of the tundra (BRYSON, 1966). The north wind is so reliable that in the field one may almost dispense with a magnetic compas for direction finding. Such prevailing winds from the tundra would probably reduce the representation of pine and spruce pollen at the Ennadai peat bank when the front lay south of Ennadai. Conversely, when the Arctic front lay north of Ennadai Lake in summer the winds from the Pacific or tropical airmasses would be from the forested regions to the west or south, and Picea and Pinus pollen would probably be greatly overrepresented at Ennadai Lake. Because of this I would predict that the modern a n u a l percentages of spruce and pine pollen deposited just north of the forest limit would vary considerably if the Arctic front shifted a few miles north or south of the site from year to year. Thus the fluctuating Picea and Sphagnum percentages may have represented a variable storm-track (i. e. frontal) location during this period.

The saw-tooth pattern of Picea representation seen in the Ennadai pollen diagram between 110 and $20 \mathrm{~cm}$ is therefore probably not an artefact of counting. It may be noted that the same analytical methods have not produced irregular pollen percentages at Lynn Lake, which is in a much less sensitive location as regards climatic and vegetational changes.

In northern Europe the later sub-Boreal period was probably somewhat cooler than the Atlantic, and towards the end there were short-term climatic variations lasting only a few centuries when cooler wetter phases or prolonged dry heat waves gave rise to recurrence surfaces and retardation layers in the peat bogs (GoDwIN, 1956).

The sporadic recurrence of Sphagnum peat growth and the peaks of Sphagnum spores between cir c a 3600 and 600 years B. P. at Ennadai are possibly of more than local significance. The Canadian "muskeg" is similar to the "blanket peat" of northern Europe, and the few radio-carbon dates available for this type of accumulation indicate that in central Canada it started to grow about 2400 years ago (Potzger \& CourTEMANCHE, 1954; $2380 \pm 90$ [WIs. 1] BENDER et al., 1965), the date of Weber's (1926) original "Grenzhorizont" (GRANLUnD’s RY III, 1932). Further possible parallelism between the past climate of northern Europe and this part of Canada may be inherent in the dates assigned to the increases in Sphagnum percentages at Ennadai which often coincide with layers of less humified peat and are thought to have registered accelerated 
peat growth under wetter conditions (cf. Tallis, 1964; Tsukada, 1966; and Fredskild, 1967). The first major rise in Sphagnum counts at Ennadai took place shortly after 3650 \pm 100 years B.P. (WIs. 80). Material underlying the successive Sphagnum peaks (and decreases in peat humification) has been assigned dates of $3140 \pm 105$ years B. P., $2670 \pm$ $105,1510 \pm 80$, and $630 \pm 70$ years B.P. (WIs. 139, 93, 88 and 133). These last four dates correspond to those which Granlund (1932) assigned (on the basis of archaeology and palynology) to the Swedish recurrence surfaces he named RY IV, III, II and I.

Radiocarbon dating has been applied to the phenomena of recurrence surfaces and retardation layers in the peat bogs of northwest Europe, and changes in peat stratigraphy have been shown to have occurred at those times which Granlund estimated, among others. However, there is some scattering of the dates inherent in this method of age determination, and there is too the problem of incorrect sampling and contamination, along with the possibility that a recurrence surface may not be synchronous at different places in the same bog (GoDwIN, 1960). Different climatic sensitivities between regions and even between topographic situations may have complicated the picture. Some locations appear to be so close to some climatic threshold which controls peat growth that they have recorded very many changes, some of which were too slight to be registered by climatically "complacent" sites. The question of the dates of these climatic events which appear to have encouraged peat regeneration is not settled, though there is general agreement on the deterioration which marks the beginning of the sub-Atlantic period $\mathrm{circa}$ 2300 to 2800 years B. P.

\section{0 to 1500 Years B.P.}

Zone A2 at Ennadai, occurring between 2600 and 1500 years B. P., was characterised by low Sphagnum counts, humified peat, irregular Picea values, increased Ericaceae percentages and the presence of sand grains in the peat at $40 \mathrm{~cm}$. At this time the spruce forest retreated or became patchy, the peat grew slowly and oxidised, and the tundra spread around Ennadai Lake. The sand grains probably represent breakdown of the local plant cover, which exposed the nearby sandy eskers to attack by wind. It seems likely that a drier, colder climate prevailed during the growing season at Ennadai, suggesting that the Arctic airmass extended south.

The suggested southward extension of the Arctic airmass would have caused the stormtrack which forms at the Arctic front to affect more southerly regions. A very great increase in the numbers of Sphagnum spores took place at Lynn Lake shortly before $2170 \pm 80$ years B.P. (WIs. 113), suggesting that areas to the south of the Arctic front in summer experienced some sort of environmental change, possibly to a colder and wetter climate during the growing season. The initiation of peat growth at Root Lake in central Manitoba began at $2380 \pm 90$ years B. P. (WIs. 1) (BENDER et al., 1965), supporting the suggestion that other areas of Manitoba experienced a climatic change at about the same time.

At Lynn Lake there was a sharp decline in Picea and Pinus percentages at $30 \mathrm{~cm}$, with a short-lived peak of Betula pollen. At this level carbonised wood was found in the peat, with charred cones of Picea mariana, and above this at 23 to $28 \mathrm{~cm}$ the peat contained unburnt Betula wood. It seems likely that a fire destroyed the local spruce-pine forest, and that birch was temporarily able to colonise the cleared land.

FREDSKILD (1967) in his work at Sermermiut, Jakobshavn, on the west coast of Greenland, found that Salix scrub was replaced by unhumified Sphagnum peat after $2570 \pm 110$ B. P. and before $2350 \pm 110$ B. P., a change he attributed to altered moisture conditions. He suggested four explanations: 1) higher precipitation in the form of rain during the summer; 2) a heavier snow-fall during autumn and winter; 3 ) a raising of the permafrost table; or 4) a lowering of the summer temperature. The fresh Sphagnum peat 
horizon was marked by very high counts of Sphagnum spores. Another Spagnum peat horizon was formed after $1940 \pm 100$ B. P. and before $1540 \pm 100$ B. P., again characterised by a peak of Sphagnum spores. FREDSKILD noted the similarity of the ages of these horizons to RY III and II of GRANLUND (1932).

The beginning of the sub-Atlantic period in northern Europe about 2500 years ago marked a widespread climatic deterioration, represented by flooding horizons, extensive peat growth, and the closing of Alpine passes by ice (Godwin, 1954, 1956). The evidence from Europe and Russia (BUCHINSKY, 1957) as LAMB (1966a) has noted seems to point to southward displacement of the depression tracks. The main recovery from the conditions, apart from some improvement around 1800 years ago, was about 1400 years B. P. A sample from $34-36 \mathrm{~cm}$ at Ennadai was dated 1250 and $1280 \pm 75$ years B. P. (Wis. 127) on two separate occasions. This is inconsistent with the numerous other dates associated with this diagram (which exhibit approximate linear accumulation with time) and the date may be disregarded. A sample immediately above this $(32-34 \mathrm{~cm})$ gave a more consistent date of $1530 \pm 80$ B. P. (Wis. 96).

\section{0 to 600 Years B.P.}

Zone A1 at Ennadai begins at about 1500 years B.P. with a peak of Picea and Sphagnum. A burned forest horizon at Dimma Lake (61 $33^{\prime} \mathrm{N}$ lat., $100^{\circ} 38^{\prime} \mathrm{W}$. long.), dated $1050 \pm 180$ B.P. or $1140 \pm 90$ B.P. (WIs. 17, BENDER et al., 1965) provides evidence for the successful growth of spruce $40 \mathrm{~km}$ north of the Ennadai peat bank (and $100 \mathrm{~km}$ north of present tree-line) during this climatically favourable period, but after the fire the forest did not regenerate at Dimma, probably due to climatic deterioration. The palynological and stratigraphic evidence probably reflected a northward migration of the forest limit after 1500 B. P., which may be interpreted as a response to a Poleward retreat of the summer position of the Arctic front. The estimated mean summer temperature at Ennadai Lake was about $1-1^{1 / 2}$ degrees $C$. above the present figure (see Fig. 5).

During the same period at Clearwater Bog near The Pas (53 $59^{\prime}$ N., $101^{\circ} 12^{\prime} \mathrm{W}$.) in central Manitoba (Nichols, 1967e) a fall in lake level exposed the beach to the accumulation of humified peat characterised by low percentages of Sphagnum spores. This is thought to represent a drier (and probably warmer) climatic episode which reflecded a northward shift of the frontal zones, and the dates of the lowest organic materials (1280 \pm 75 B.P., Wis. 146; and $940 \pm 60$ B.P., Wis. 173, BENDER et al., 1967) are consistent with the evidence of a milder climate in Keewatin at this time.

There was a fall in Alnus and Sphagnum values at Lynn Lake at $15 \mathrm{~cm}$, and a rise of Picea and Pinus percentages. At $14 \mathrm{~cm}$ there was a layer of sand $2 \mathrm{~mm}$ thick, and above this the peat was generally humified, with Sphagnum mosses composing most of the organic accumulation above $12 \mathrm{~cm}$. A sample of peat from 14 to $16 \mathrm{~cm}$ was dated $1550 \pm$ 50 B. P. (Wis. 225, Bender et al., unpub.). This seems to be a reflection of some sort of environmental change at this period, though no unequivocal interpretation can yet be given. It is possible that the stratigraphic change from telmatic sedge peat to terrestrial Sphagnum peat reflected a lowering of lake level, but the possibility that this may have been a response to a drier warmer climate cannot be discussed here.

From about 1400 to 700 years B. P. the climate of northern Europe was characterised by anticyclonic conditions, with hot summers and short cold winters (BROOKs, 1949; Lамв, 1963, 1966a). There was little cyclonic storminess in the North Atlantic so that the Norse voyages to Greenland and Vinland, and the establishment of colonies, were made during calmer weather and with little contact with sea-ice. Retardation layers in north European bogs point to the decrease of summer cyclonic rainfall. A humified layer 
attributable to dry conditions began at $1477 \pm 90$ B. P. (Q-391) and ended at $768 \pm 90$ B. P. (Q-390) at a peat bog in Wales, (Godwin \& WiLlis, 1960). Depression tracks appear to have been situated farther north, and mean summer temperatures in Europe are estimated to have been about 1 degree C. higher than the modern normal (LAMB, 1963).

A final peak in Picea representation at Ennadai was followed by a prolonged decline, and there was no increase of other arboreal pollen to take its place. Instead, numbers of nonarboreal pollen rose, particularly those of the Ericales. Sphagnum percentages declined, the peat became very humified, and after a small peak in $S$ phagnum spores at $5 \mathrm{~cm}$ the peat stopped growing, about 600 years ago. This, I suggest, reflects a southward extension of the summer position of the Arctic airmass, bringing a colder, drier climate to Ennadai and resulting in a retreat of the forest to the south of Ennadai peat bank, the establishment of tundra vegetation at the north end of Ennadai Lake, and the cessation of peat growth.

A question arises concerning the humification of the top $20 \mathrm{~cm}$ of material from Ennadai Lake - is it primary or secondary oxidation? Peat growth in this area seems to have occurred most rapidly under warm wet conditions when the Arctic front was north of the site, and it accumulated slowly, if at all, when the Arctic airmass dominated Ennadai throughout the year. This organic accumulation is therefore most likely to have occurred under the relatively warm climate from ca. 1500 to ca. 600 years B. P. Since the peat stopped accumulating at that latter time, oxidation of the underlying material to a depth limited by the brief summer thaw could take place. Under the present climatic conditions peat at Ennadai Lake thaws to approximately $35 \mathrm{~cm}$ each summer. The upper $20 \mathrm{~cm}$ of peat at Ennadai which is humified has therefore been liable to oxidation.

The upper $20 \mathrm{~cm}$ of peat at Ennadai is composed primarily of Sphagnum mosses. The only Ericaceous material which is present consists of roots which appear to have penetrated the face of the peat bank after its accumulation. Since this upper peat contains no contemporary material representative of a full tundra climate (such as leaves of Ledum palustre and Vaccinium vitis-idaea which grow on the modern peat surface) it is probable that accumulation occurred during a period of non-tundra climate, and that the humification is secondary.

There were still trees at the north end of Ennadai Lake $880 \pm 180$ years ago, for charred wood from a site $5 \mathrm{~km}$ south of the Ennadai peak bank (Ennadai Aeradio Station) was assigned that date (WIs. 5, BENDER et al., 1965). However, no charcoal has been found at the Ennadai peat bank from that period. It is possible that by about 900 years ago the tree-line had already retreated a few miles south of the Ennadai site, and that the fire was confined to the forest, having no effect on the tundra vegetation which now occupied the Ennadai peat bank. After the fire had destroyed the forest at the Aeradio Station the tree-line continued to move south, following the movement of the Arctic front, and for the last eight centuries the area at the northern end of Ennadai Lake has remained covered by tundra and apparently undisturbed by fires.

The latest climatic deterioration recorded at Ennadai occurred at the same time as worsening climatic conditions in northern Europe inhibited the voyages of the Scandinavians between Vinland, Greenland and Norway (cf. The Vinland Sagas). Sailors in the North Atlantic during the thirteenth century reported more sea-ice than previously, and greater numbers of storms increased the difficulty of supplying Greenland with food. Contact was lost with the Greenland settlements and the colonists perished. The recurrence of peat growth in northern Europe at about this time may have been due to an increase of the precipitation-evaporation ratio in summer perhaps connected with a shift of the depression tracks to lower latitudes (LAMB, 1966a). Numerous bad harvests were recorded in the fourteenth century (BROOKs, 1949). Though there was an improvement in the fifteenth century, by the late sixteenth century the biggest glacial advance of the 
post-glacial period had begun (this was the "Little Ice Age"), and there was no major improvement in climate until about 1850 (LAMB, 1963).

The failure of the peat Ennadai to resume growth in the last 600 years suggests that central Canada shared with northern Europe the rigorous climate which came to an end only in the nineteenth century, and which has shown signs of reasserting itself in the last twenty years.

\section{Notes on Pinus Pollen}

The presence of Pinus pollen in the Ennadai diagram need not imply local growth of pine. This tree does not at present grow (other than as isolated individuals) at the northern edge of the Boreal forest in the neighbourhood of Ennadai Lake (LARSEN, personal communication) but is found as pure stands farther south. The values for Pinus pollen in the Ennadai diagram have a high inverse correlation with the numbers of Picea pollen. I suggest that this was largely due to long-distance transport of Pinus pollen, a background pollen rain from pines growing to the south and west which became overrepresented when the locally-dominant pollen producer, Picea, was adversely affected. An example is seen at the top of the Ennadai diagram: as the forest limit retreated south and tundra spread around Ennadai the decline of Picea pollen was matched by a rise in Pinus percentages (at 5 and $0 \mathrm{~cm}$ ). Some of this reciprocity may have been due to the ability of Pinus banksiana to colonise ground cleared by fire, but no macrofossils of pine have been found in the Ennadai peat, and its invasion of the area remains doubtful. At Lynn Lake pine was present with spruce throughout most of the post-glacial period, but the pollen percentages for these genera were broadly parallel from about $5100 \mathrm{~B}$. P. to the modern surface, even at times of disturbance by fire (e.g. at 20 to $35 \mathrm{~cm}$ ).

Conclusions

The vegetational histories of Ennadai Lake and Lynn Lake appear to be mutually consistent and are explicable in climatic terms, particularly with reference to the work of BRYSON (1966). These diagrams are however the first from the very large area of central and northern Canada to be closely dated by the radiocarbon method, and inferences based on them must necessarily remain tentative until the investigation of other sites is completed. The events which are described here are in accord with the generalised pattern of climatic change in Canada which was summarised by Terasmae (1961), which was however based primarily on evidence from southern and especially south-eastern Canada.

Throughout this account I have introduced references to the climatic history of northwest Europe to draw attention to the points of similarity in the records of the two regions. The north European palynological evidence is based on numerous sites and many radiocarbon determinations, but the effect of man's activities on the vegetation and the difficulty of distinguishing the (often short-lived) post-Atlantic climatic episodes from the (at present) equivocal record of peat stratigraphy has complicated the comparison of the central Canadian and north European records.

This initial and necessarily tentative comparison has however revealed a number of interesting similarities, and it may ultimately be confirmed that the climatic histories of central Canada and northwest Europe were parallel for the past 6000 years, and that the climatic changes experienced by both areas were synchronous. That this might be so is not surprising, for the nature of the atmospheric circulation of the Northern Hemisphere makes climatic parallelism between these regions very likely. There is an excellent summary of the factors involved in a paper by LAMB, $(1964, \mathrm{p} .1)$. These results lend support to the concept that the atmospheric circulation of the Northern Hemisphere may be treated as an entity, and stronger correlations between the climatic histories of parts of North America, Europe and Russia may be expected. 
The use of modern meteorological analogies in palaeoclimatic studies leads to the recognition that since at present the continental land masses are not characterised by a single type of climate but by many, one may expect in the palynological investigation of large areas to encounter similar diversities in palaeo-climate. A modern example of this diversity is the persistent weather fluctuation since about 1960 which has resulted in drought in the northeastern states of the U.S. and wetter conditions in the northern plains and southwest of the U.S.A. (Namias, 1966 and cf. Wexler, 1956). The effect of this recent climatic change on world temperatures and rainfall is discussed by LAMB (1966b and cf. 1965). There is no need to expect a whole continent to become wetter or drier simultaneously, but it is reasonable to suppose that shifts of airmasses and stormtracks would make some regions more rainy while neighbouring areas received less precipitation than formerly.

The possibility of similarity in the post-glacial climatic history of central Canada and northwest Europe may eventually provide a check on those problematical events in either region which would benefit from external verification. One example concerns the opening of the sub-Boreal period in Europe about 5000 years ago, and the meaning of the "elm decline". The anthropogenic factors which disturbed the natural European vegetation and obscured the effects of climatic change for at least the last five millennia did not operate in central Canada until very recently. I suggest from the comparative Canadian evidence that northern Europe (and other parts of the Northern Hemisphere) may have experienced a short cooling episode approximately 5000 years ago. This might have contributed to the very widespread decline of Ulmus pollen percentages which some workers have regarded as being too universal in European pollen diagrams to reflect solely the activities of Neolithic farmers. This is not to deny the effect of cultural activities but to suggest that a widespread climatic change did occur at approximately the same time as the expansion of Neolithic agriculture in northern Europe. The coincidence of climatic and cultural changes, and their possible relationship, has been the subject of comment by Nichols (1967f). Frenzel (1966) has provided a valuable summary of the evidence for climatic change at the Atlantic/sub-Boreal transition, and makes a strong case for such a phenomenon in Europe.

The north European sequence of climatic and vegetational events for approximately the last 2000 years has been clarified by reference to archaeology and to written records (Oldfield, 1963; Turner, 1964; Mitchell, 1965) and for the past few centuries by instrumental records (MANLEY, 1965). Climatic changes lasting for a few hundred years have been identified (LAMB, 1961, 1963) and the chronology established has probably less error than that inherent in the radiocarbon method. This applies particularly to the last 200 years, for within this period C-14 assay is incapable of providing an accurate date. Canada lacks such ancient records, but if climatic synchrony and parallelism between central Canada and northern Europe are ultimately confirmed, then former climatic events in Canada may be more confidently compared with the more detailed written accounts of such phenomena from Europe.

A cknowledgment

I wish to thank particularly Dr. Margaret BENDER for determining the radiocarbon dates and Professor Reid BRYSON and Mr. Wayne WENDLAND for discussing climatic problems. I am very grateful to Dr. W. S. G. MAAss for identifying mosses from the Ennadai peat. Wood identification was by Drs. R. C. Koeppen and B. F. KuкAchкA, U. S. Forest Products Laboratory, Madison, Wisconsin, U.S. A., and the illustrations were by Mr. David Woodward. I am indebted to Professor H. Godwin, F. R. S., Professor F Oldfield, and Dr. R. G. West for criticism of the manuscript. Research supported by Atmospheric Sciences Division, NSF (GP-5572 x). 


\section{References}

Bender, M. M., R. A. Bryson \& D. A. Baerreis: Univ. Wisconsin Radiocarbon Dates, I. Radiocarbon, 7, 399-407, 1965. - - Univ. Wisconsin Radiocarbon Dates, II. Radiocarbon, 8, 522-533, 1966. - - Univ. Wisconsin Radiocarbon Dates, III. Radiocarbon, 9, 530-544. - Univ. Wisconsin Radiocarbon Dates, IV. (unpub.)

Brooks, C. E. P.: Climate through the ages. pp. 395, McGraw-Hill, New York 1949.

Bryson, R. A.: Air masses, streamlines, and the Boreal forest. Geogr. Bull., 8 (3), 228-269, 1966.

Bryson, R. A., W. N. Irving and J. A. LARSEN: Radiocarbon and soils evidence of former forest in the southern Canadian tundra. Science, 147, 46-48, 1965.

BUCHINSKY, I. E.: The past climate of the Russian plain. Leningrad 1957.

Falconer, G., J. D. Ives, O. H. LøKen, \& J. T. Andrews: Major end moraines in Eastern and Central Arctic Canada. Geogr. Bull., 7 (2), 137-153, 1965.

Fredskild, B.: Palaeobotanical investigations at Sermermiut, Jakobshavn, West Greenland. Medd. om Grønland, 178 (4), 54 pp., 1967.

Frenzel, B.: Climatic change in the Atlantic/sub-Boreal transition on the Northern Hemisphere: botanical evidence. In: World Climate from 8000 to 0 B. C., Roy. Meteor. Soc., London, 99-123, 1966.

Godwin, H.: Recurrence surfaces. Danm. Geol. Unders., 2 (80), 22-30, 1954. - - History of the British flora. pp. 384, Cambridge 1956. - - Radiocarbon dating and Quaternary history in Britain. Proc. Roy. Soc. London, B (153), 287-320, 1960.

Godwin, H., R. P. Suggate, \& E. H. Willis: Radiocarbon dating of the eustatic rise in oceanlevel. Nature, 181, 1518-1519, 1958.

Godwin, H., \& E. H. Willis: Cambridge University natural radiocarbon measurements, II. Am. J. Sci., Radioc. Supp., 2, 62-72, 1960.

Granlund, E.: De svenska Hogmossernas geologi. Sverig. Geol. Unders. Afh., 5 (1), c 373, 1932.

Hare, F. K.: Some climatological problems of the Arctic and sub-Arctic. In: Malone, T. E. (ed.), Compendium of Meteorology, Am. Met. Soc., Boston, 952-964, 1951.

Huschke, R. E. (ed.): Glossary of meteorology. Am. Met. Soc., Boston, Mass., pp. 638, 1959.

Iversen, J.: Landnam i Danmarks Stenalder. Danm. Geol. Unders., 2 (66), pp. 68, 1941. - Problems of the early Post-Glacial forest development in Denmark. Danm. Geol. Unders., 4 (4), pp. 32, 1960.

Knollenberg, R.: The distribution of string bogs in central Canada in relation to climate. Techn. Rep. 14, Dept. Met., Univ. Wisconsin, 1964.

LAMB, H. H.: Climatic change within historical time as seen in circulation maps and diagrams. Ann. New York Acad. Sci., 95 (1), 124-161, 1961. - - On the nature of certain climatic epochs which differed from the modern (1900-39) normal. Proc. W.M.O./U.N.E.S.C.O., Rome (1961) Symposium on climatic changes (Arid Zone XX), 125-150, Paris, U.N.E.S.C.O., 1963. - - Atmospheric circulation and climatic changes in Europe since 800 A. D. Rep. VI INQUA Congr., Warsaw, 1961, II, 291-318, 1964. - - Britain's changing climate. In: The biological significance of climatic change in Britain (ed. C. G. Johnson \& L. P. Smith), pp. 222, London, 1965. - - The changing climate. pp. 236, London, 1966(a). - - Climate in the 1960's. Geogr. J. 132 (2), 183-212, 1966(b).

LARSEN, J. A.: An outline of materials for a postglacial bioclimatic history of Keewatin, Northwest Territories, Canada. Techn. Rep., 15, Dept. Met., Univ. Wisconsin, 1964(a). - The role of physiology and environment in the distribution of Arctic plants. Techn. Rep., 16, Dept. Met., Univ. Wisconsin, 1964(b). - - Geographical position of the central Canadian northern forest border. (unpub.) 1965(a). - - The vegetation of the Ennadai Lake area, N.W.T.: studies in Subarctic and Arctic bioclimatology. Ecol. Monogr., 35, 37-59, 1965(b). - - Relationship of central Canadian Boreal plant communities: studies in Subarctic and Arctic bioclimatology, II. Techn. Rep., 26, Dept. Met., Univ. Wisconsin, 1966(a). - - Soils of the Boreal forest: a preliminary survey. Techn. Rep., 25, Dept. Met., Univ. Wisconsin, 1966(b).

LEE, H. A.: Surficial geology of the southern district of Keewatin and the Keewatin ice divide, Northwest Territories. Geol. Surv. Canada Bull., 51, pp. 42, Ottawa, 1959.

Lettau, B.: The use of sub-Arctic bogs as natural climatic indicators. Techn. Rep., 23, Dept. Met., Univ. Wisconsin, 1966.

Lichti-Federovich, S., \& J. C. Ritchie: Contemporary pollen in central Canada, II. The forestgrassland transition in Manitoba. Pollen et Spores, VII (1), 63-87, 1965.

MaAss, W. S. G.: National Research Council, Halifax, Nova Scotia, Canada. Written communication, 7-3-1966.

Manley, G.: Possible climatic agencies in the development of post-Glacial habitats. Proc. Roy. Soc., B (161), 363-375, 1965. 
McFadden, J. D.: The inter-relationship of lake ice and climate in central Canada. Techn. Rep., 20, Dept. Met., Univ. Wisconsin, 1965.

Mrtchell, G. F.: Littleton bog, Tipperary: an Irish vegetational record. In: Intern. stud. on the Quaternary (H. E. Wright \& D. G. Frex, ed.), 1-16, Princeton, 1965.

Namias, J.: Nature and possible causes of the north-eastern United States drought during 1962-65. Monthly Weath. Rev., 94 (9), 543-554, 1966.

Nichols, H.: Pollen diagrams from sub-arctic central Canada. Science, 155, 1665-1668, 1967(a). - Central Canadian palynology and its relevance to northwestern Europe in the late Quaternary period. Proc. 2 cl Intern. Palyn. Conf., Utrecht, 1966, 1967(b) (in press). - Pollen diagrams from Pelly Lake, Northern Keewatin. (unpub.) 1967(d). - - A pollen diagram from Clearwater Bog, The Pas, Manitoba. (unpub.) 1967(e). - - Vegetational change, shoreline displacement, and the human factor in the late-Quaternary history of southwest Scotland. Trans. Roy. Soc. Edinburgh, 67, 145-187, 1967(f).

Oldfield, F.: Pollen analysis and man's role in the ecological history of the S. E. Lake District. Geogr. Ann., 45(1), 23-40, 1963.

Peterson, J. T.: On the distribution of lake temperatures in central Canada as observed from the air. Techn. Rep., 22, Dept. Met., University Wisconsin, Madison, 1965.

Porter, S. C., \& G. H. Denton: Chronology of neoglaciation in the North American Cordillera. Am. J. Sci., 265, 177-210, 1967.

Potzger, J. E., \& A. Courtemanche: A radiocarbon date of peat from James Bay, Quebec. Science, 119, 908-909, 1954.

Ritchie, J. C.: The native plants of Churchill, Manitoba, Canada. Canad. J. Bot., 34, 269-320, 1956 (a). - - The vegetation of northern Manitoba. I. Studies in the southern spruce forest zone. Canad. J. Bot., 34, 523-61, 1956(b). - - The vegetation of northern Manitoba. II. A prisere on the Hudson Bay lowlands. Ecology, 38, 429-35, 1957. - - The vegetation of northern Manitoba. III. Studies in the subarctic. Arctic Inst. North Am. Techn. Paper, 3, 1-56, 1959. - - The vegetation of northern Manitoba. IV. The Caribou Lake region. Canad. J. Bot., 38, 185-199, 1960(a). - - The vegetation of northern Manitoba. VI. The lower Hayes River region. Canad. J. Bot., 38, 769-88, 1960(b). - The vegetation of northern Manitoba. V. Establishing the major zonation. Arctic, 13, 211-29, 1960(c). - - A geobotanical survey of northern Manitoba. Arctic Inst. North Am. Techn. Paper, 9, 1-46, 1962. - - Contributions to the Holocene palaeoecology of westcentral Canada. I. The Riding Mountain area. Can. J. Bot., 42, 181-196, 1964.

Sharp, R. P.: Malaspina Glacier, Alaska. Bull. Geol. Soc. Am., 69, 617-646, 1958.

Smith, A. G.: The Atlantic-Sub-boreal transition. Linn. Soc. Proc., 172, 38-49, 1961. - - Problems of inertia and threshold related to post-Glacial habitat changes. Proc. Roy. Soc., B (161), 331-342, 1965.

TAllis, J. H.: Studies on southern Pennine peats III. The behaviour of Sphagnum. J. Ecol., 52, 345-353, 1964.

Terasmae, J.: Notes on late-Quaternary climatic changes in Canada. Ann. New York Acad. Sci., 95(1), 658-675, 1961.

Troels-Smith, J.: Ivy, mistletoe and elm. Climatic indicators-fodder plants. Danm. Geol. Unders., IV, 4, 4, 1960.

Tsukada, M.: Pollen succession, absolute pollen frequency, and recurrence surfaces in central Japan. Am. J. Bot., 54, 7, 821-831, 1967.

Turner, J.: The anthropogenic factor in vegetational history, 1. Tregaron and Whixall Mosses. New Phytol., 63, 73-90, 1964.

Trrrell, J. B.: Changes in climate in northwestern Canada since the glacial period. Die Veränderungen des Klimas seit dem Maximum der letzten Eiszeit. 11th Inter. Geol. Cong., Stockholm, 389-91, 1910.

Vinland Sagas, the. Translated by M. Majnusson and H. Palsson, Penguin Books, 124 pp., Harmondsworth, 1965.

Weber, C. A.: Grenzhorizont und Klimaschwankungen. Abh. Naturw. Ver. Bremen, 28, 98-106, 1926.

Wendland, W.: Analysis of measured net radiation values for Canada. Geog. Bull., 9, 1, 1-10, 1967.

WeXLER, H.: Variations in insolation, general circulation and climate. Tellus, 8, 480-494, 1956.

Manuskr. eingeg. 22. 5. 1967.

Anschrift des Verf.: Harvey Nichols, Ph. D., University of Wisconsin, Department of Meteorology, 733 University Avenue, Madison, Wisconsin 53706, U.S.A. 